\title{
Goods and Services Tax Efficiency across Indian States: Panel Stochastic Frontier Analysis
}

No. 310

15-July-2020

Sacchidananda Mukherjee 


\title{
Goods and Services Tax Efficiency across Indian States: Panel Stochastic Frontier Analysis
}

\author{
Sacchidananda Mukherjee
}

\begin{abstract}
In public finance, estimation of tax potential of a government - either federal or provincial - has immense importance to understand future streams of tax revenue. Tax potential depends on tax capacity and tax effort (TE) and therefore joint estimation of both the functions is desirable. There are several frameworks to estimate tax capacity and tax efficiency (tax effort); in the present paper time variant truncated panel Stochastic Frontier Approach (SFA) is adopted to estimate the functions jointly for the period 2012-13 to 201920. The findings of the study could be useful for policy and especially for the sitting Fifteen Finance Commission. The results of the study show that GST capacity of states depends on size and structural composition of the economy. Introduction of GST has reduced states' GST capacity and the impact is restricted to scale only. The study has used data from GST Network (GSTN) database for the post-GST period and given all other factors at their levels, GSTN data shows lower GST capacity for high income states and higher capacity for low income states. The relationship between per capita income (PCI) of states and tax efficiency is non-linear and as PCI rises TE falls and thereafter it rises. Minor states (special category states and UTs with legislative assembly) have lower tax efficiency. Delhi and Goa have the highest GST gap and on average major states could increase their GST collection by 0.52 percent of GSVA and minor states by 1.15 percent if they increase their tax efforts.
\end{abstract}

Key Words: Tax capacity, Tax efficiency, Goods and Services Tax (GST), Value Added Tax (VAT), Stochastic Frontier Approach, Panel Data Analysis, States of India.

JEL Codes: H21, H71, H77 


\section{Introduction}

A comprehensive multistage Value Added Tax (VAT) system, namely Goods and Services Tax (GST), is introduced in India since 1 July 2017. GST encompasses various taxes from the union and state indirect tax bases, and it is a dual VAT system with concurrent taxation power to the union (federal) and state (provincial or sub-national) governments. The shift from origin-based VAT system to destination-based GST system is expected to reduce horizontal fiscal imbalance among Indian states. It is also expected that states having larger consumption base will gain from GST as compared to states having larger production base.

It would be difficult to comment on success of the GST system in terms of revenue mobilization, as the new tax system is yet to be stabilized. However, GST collection is falling short of desired targets set in successive Union Budgets. The genesis of the revenue shortfall may be GST design and structural in nature and/or compliance and tax administration related. However, the uncertainty surrounding GST revenue collection is an issue which needs an in-depth assessment for fiscal management of the union and state governments. Understanding states' capacity in GST collection is important which may help in charting out prospecting path of public finance management of Indian states. A considerable part of India's indirect tax base is subsumed in GST and therefore any revenue shock in GST collection may result in fiscal shock to Indian public finance. Unlike the union government, states have limited revenue sources (or taxation power / tax handles) to compensate for substantial revenue loss on account of GST collection. In the face of revenue shortfall on account of GST, states not only face direct revenue shock on account of state GST (SGST) collection but also indirectly in terms of lower receipts of tax devolution from the union government.

To moderate the revenue impacts on state finances due to uncertainty surrounding GST revenue collection, the union government assured states to protect their revenue that is subsumed in GST during the GST transition period (1 July 2017 to 30 June 2022). However, GST compensation is expected to end on 30 June 2022 and therefore understanding states' own capacity to collect GST has immense importance, given the ongoing face-off between union and states for the delay in releasing GST compensation payments to states.

Tax collection depends on tax capacity and tax effort (or efficiency) of a country or state. Being consumption based tax; tax capacity of state in GST depends on consumption base of a state. Given tax capacity, tax collection varies across states due to differences in tax efficiency (tax effort). In principle VAT / GST gap comprises of compliance gap and policy gap (Nerudova and Dobranschi 2019). Compliance gap measures the difference between actual GST revenues and the potential GST revenues that could have been collected had no taxpayer been involved in any tax evasion or tax avoidance. Policy gap represents the uncollected GST revenues due to differences in GST rates across commodities, exemptions, thresholds, abatements etc. Therefore, the policy gap is the difference between the actual GST revenues and the theoretical GST revenues that would have been collected if a standard GST rate on all 
consumption of goods and services is imposed. Even if in a harmonized system of GST, policy gap may vary across states depending on structure of aggregate consumption of the state (e.g., relative shares of taxed vs. exempted goods and services, relative shares of high taxed vs. low tax goods and services) and structure of businesses (e.g., formal vs. informal, distribution of annual turnover across businesses). Tax compliance is function of tax effort. Since tax collection is a political decision, political interference in tax administration and tax enforcement is another exogenous factor which may influence tax effort and therefore in tax compliance.

Given the data available in the public domain, we estimate tax capacity and tax efficiency of Indian states with respect to state GST collection for the period 2012-13 to 2019-20. For the period 2012-13 to 2017-18 (upto 30 June 2017), we have taken state-wise revenue subsumed in GST to match with the data post-GST regime (state GST collection including Integrated GST settlement). In the next section we present a comprehensive review of literature specific to state-specific studies in India. In section 3, we present methodology of the study and in section 4 we discuss on data sources and their constraints. In section 5 we present our results and estimate potential GST gap across states. We draw our conclusions in section 6 . In our knowledge, there is no study which estimates GST efficiencies of Indian states and therefore the present paper fills the gap in literature.

\section{Literature Review}

Estimation of tax efficiency has always been an area of research in public finance both from cross-country and within a country from sub-national perspective. Methodologies in estimation of tax efficiency have evolved from income approach, representative tax system (RTS) approach, regression approach to stochastic frontier analysis (SFA). Indicators of tax base or tax capacity for particular tax or taxes and tax efficiency (or tax effort) vary across these approaches. For example, in income approach national (or subnational) income is taken as the tax base and the ratio of tax collection to national (or subnational) income as the tax effort. This approach is based on the assumption that national income perfectly captures the tax base. Being consumption based tax; subnational income (or gross state domestic product [GSDP]) may not be the only indicator of tax base for tax like VAT or GST. Therefore, the income approach is not the right approach for our analysis. Purohit (2006) ranks Indian states according to their tax effort based on this approach. Coondoo et al. (2001) use a modified income approach where the ordinal position of the states in the tax-GSDP ratio is captured through quintile regression.

In the RTS approach, "[T] axable capacity is defined ... as the total tax amount that would be collected if each country applied an identical set of effective rates to the selected tax bases, that is, as the yield of a representative tax system" (Bahl 1972). However, universal effective tax rate across commodities is a very strong assumption for a country like India where multiple tax rates prevail. In addition, tax base may also vary for a representative tax across states due to the differences in consumption pattern and structure of businesses. In 
this approach, the ratio of actual tax collection to the yield of the RTS is taken as tax effort. Given the difficulties involved in the estimation of effective tax rate and tax base, this approach is not suitable for our analysis. Rao (1993) used a modified RTS approach for the estimation of tax effort across Indian states.

In the regression approach, the actual tax revenue-to-income ratio is regressed on a set of independent variables, to capture the tax base, and the residual of the regression model, which is the difference between the actual tax revenue-to-income ratio and the estimated tax revenue-to-income ratio, is considered the tax effort. In this method, the regression error (or disturbance), which may contain a random component, is also considered as the tax effort. This method is adopted by many studies specific to Indian states (Oommen 1987, Rao 1993, Sen 1997, Thimmaiah 1979), however this approach is not a suitable framework for our analysis.

So far there are four published studies based on the SFA approach which estimate tax capacity and tax efficiency for Indian states. These studies vary in many features: (a) methodology adopted, (b) in capturing indicators for estimation of tax capacity and tax effort, (c) time period for analysis, (d) in selecting the states and (e) in selecting taxes.

Jha et al. (1999) identified that for the period 1980-1981 to 1992-1993, state domestic product (SDP or GSDP), proportion of agricultural income to total SDP (AGY) and time series trend (captured through year or time variable) are the major factors determining own tax revenue (OTR) capacity of 17 major Indian states. The study found a positive relationship between SDP and OTR and a negative relationship between share of agriculture in GSDP and OTR. The study adopts time variant SFA as developed by Battese and Coelli (1995) and explores some variables influencing tax effort as well.

Garg et al. (2014) found that for the period 1992-1993 to 2010-2011, per capita real GSDP, share of agriculture in GSDP, literacy rate, labour force, road density and urban Gini (a measure of consumption inequality) influence OTR (as percentage of GSDP) capacity for 14 major states. Except square of per capita real GSDP and share of agriculture in GSDP, all other independent variables have positive and significant relationship with OTR collection of the states. This study uses Battese and Coelli (1995) methodology for simultaneous estimation of tax capacity and tax efficiency across Indian states.

Karnik and Raju (2015) found that for the period 2000-2001 to 2010-2011, sectoral share of manufacturing in GSDP and annual per capita consumption expenditure are the major determinants for sales tax (as percentage of GSDP) capacity for 17 major Indian states. Both the variables have positive and significant relationship with state's sales tax collection. This study estimates time invariant SFA models and do not incorporate efficiency factors in the model.

Mukherjee (2019) found that for the period 2001-2002 to 2015-2016, tax 
(comprehensive VAT) capacity of states is a function of the scale of economic activity (measured by GSDP) and of the structural composition of the economy. Tax capacity is lower in states that have a larger share of manufacturing and mining or industry vis-a-vis agriculture in GSDP and larger in states that have a larger share of services in GSDP vis-a-vis agriculture. The change in prices of mineral oils as measured by the wholesale price index (WPI) of mineral oils has a positive and significant impact on tax capacity. Tax capacity is larger in states that have seaports and petroleum refineries. This study uses Battese and Coelli (1995) methodology for simultaneous estimation of tax capacity and tax efficiency across Indian states.

In estimation of tax efficiency function, Jha et al. (1999) found that share of central government grants in total state government expenditure (GTOE), interaction term of GTOE and Gross State Domestic Product (SDP), interaction term of GTOE and Share of Agriculture in GSDP (AGY), per capita real rural household consumption expenditure (CO) and Time are significant factors influencing tax inefficiency. Except $\mathrm{CO}$ all other factors have positive and significant impact on tax inefficiency. Alternatively, except $\mathrm{CO}$ all other factors influence tax efficiency negatively.

Garg et al. (2014) found that one year lag value of 'ratio of transfers net of loan to revenue receipts', 'ratio of total expenditure to GSDP', 'ratio of outstanding liabilities to GSDP', 'ratio of debt repayment to total revenue', 'governance index', significantly influence tax inefficiency. In addition, years after implementation of Fiscal Responsibility Budget Management (FRBM) Act in the state (FRBMA dummy) and Effective Number of Political Parties at the State level (ENP) influence tax inefficiency significantly. Except 'ratio of transfers net of loan to revenue receipts', all other factors influence tax inefficiency negatively.

Mukherjee (2019) found a non-linear relationship between per capita income and tax efficiency. With rising per capita income tax efficiency increases and reaches a plateau and with further rise in per capita income, tax efficiency falls. The study found inter-governmental fiscal transfers do not increase tax efficiency. In other words, states where a large part of their expenditures is financed through central transfers put less tax effort. States where a larger share of total expenditure is financed through revenue from royalties put larger tax effort. The introduction of VAT across states has resulted in fall in tax effort whereas the enactment of FRBM Act has positively influenced tax efficiency. The result shows that tax efficiency is not independent of election cycle of state legislative assembly. Tax efficiency goes up in the year of election when new government is formed by a different political party or alliance.

There are considerable numbers of cross-country studies where tax efficiencies of general governments are estimated (Stotsky and WoldeMariam 1997, Davoodi and Grigorian 2007, Mikesell 2007, Bird et al. 2008, Le et al. 2012, Fenochietto and Pessino 2013, Cyan et al. 2013, Langford and Ohlenburg 2016, Brun and Diakité 2016). However, such studies have limited use in policy as tax base varies across taxes and therefore analyzing consolidated tax 
revenue may not be right framework of analysis. Moreover for a federal country like India tax administration varies across jurisdictions. Even within a tax (say state VAT) design and structural features along with rules and regulations vary across jurisdictions.

Indian GST is a tax system where design, structure, rules and regulations are harmonized across Indian states and also certain tax administration functions are centralized under the GST Network (e.g., tax registration, return submissions, tax payments). Therefore, analyzing GST efficiency of Indian states is a perfect case for the objective of our analysis.

\section{Methodology}

Following Battese and Coelli (1995), stochastic production function for panel data can be written as:

Where,

$$
\mathrm{Y}_{\mathrm{it}}=\exp \left(\mathrm{x}_{\mathrm{it}} \beta+\mathrm{V}_{\mathrm{it}}-\mathrm{U}_{\mathrm{it}}\right)
$$

$\mathrm{Y}_{\mathrm{it}}$ denotes the production of the ith firm $(\mathrm{i}=1,2,3, \ldots, \mathrm{N})$ for the th year $(\mathrm{t}=1,2, \ldots, \mathrm{T})$;

$\mathrm{x}_{\mathrm{it}}$ is a $(1 \mathrm{x} \mathrm{k})$ vector of values of known function of inputs of production and other explanatory variables associated with the ith firm at the th year;

$\beta$ is a ( $\mathrm{k} \times 1)$ vector of unknown parameters to be estimated;

the $\mathrm{V}_{\text {itt }} \mathrm{S}$ are assumed to be iid $N\left(0, \sigma_{v}^{2}\right)$ random errors (also known as idiosyncratic error), independently distributed of the $U_{i t} S$;

the $U_{i t} S$ are non-negative random variables, associated with technical inefficiency of production, which are assumed to be independently distributed, such that $U_{i t}$ is obtained by truncation (at zero) of the normal distribution with mean, $\mathrm{z}_{\mathrm{it}} \delta$, and variance, $\sigma_{\mathrm{u}}^{2}$;

Equation (1) specifies the stochastic frontier function in terms of the original production values. However, the technical inefficiency effects, the $U_{\mathrm{it}} \mathrm{S}$ are assumed to be a function of a set of explanatory variables, the $\mathrm{z}_{\mathrm{it}} \mathrm{S}$ and an unknown vector of coefficients, $\delta$. The variables in the inefficiency model may include some input variables in the stochastic frontier, provided the inefficiency effects are stochastic.

The technical inefficiency effect, $U_{i t}$, in the stochastic frontier model (1) could be specified in explanatory equation (2),

Where,

$$
\mathrm{U}_{\mathrm{it}}=\mathrm{Z}_{\mathrm{it}} \delta+\mathrm{W}_{\mathrm{it}}
$$

$\mathrm{Z}_{\mathrm{it}}$ is a $(1 \mathrm{x} \mathrm{m})$ vector of explanatory variables associated with technical inefficiency of production of firms over time; and

$\delta$ is an ( $\mathrm{m} x 1)$ vector of unknown coefficients.

Where the random variable, $\mathrm{W}_{\mathrm{it}}$, is defined by the truncation of the normal distribution with zero mean and variance, $\sigma_{\mathrm{u}}{ }^{2}$, such that the point of truncation is $\mathrm{z}_{\mathrm{it}} \delta$, i.e., $\mathrm{W}_{\mathrm{it}} \geq-\mathrm{Z}_{\mathrm{it}} \delta$. 
These assumptions are consistent with $U_{i t}$ being a non-negative truncation of the $N\left(z_{i t} \delta, \sigma_{u}{ }^{2}\right)$ distribution. W-random variables are identically distributed and non-negative. The mean, $\mathrm{z}_{\mathrm{it}} \delta$, of the normal distribution, which is truncated at zero to obtain the distribution of $\mathrm{U}_{\mathrm{it}}$, is not required to be positive for each observation.

The method of maximum likelihood is proposed for simultaneous estimation of the parameters of the stochastic frontier and the model for the technical inefficiency effects. The likelihood function and its partial derivatives with respect to the parameters of the model are presented in Battaese and Coelli (1993). The estimated total error variance is $\sigma_{\mathrm{s}}^{2}=\sigma_{\mathrm{v}}{ }^{2}+$ $\sigma_{\mathrm{u}}{ }^{2}$ and the ratio of the standard deviation of the inefficiency component to the standard deviation of the idiosyncratic component is labelled as lambda $\left(\lambda \equiv \frac{\sigma_{u}}{\sigma_{v}}\right)$. The estimated $\lambda$ is non-negative and significant. Value of gamma $\left(\gamma \equiv \sigma_{u}^{2} / \sigma_{s}^{2}\right)$ must lie between zero and one with values of 0 indicating the deviations from the frontier are entirely due to noise (idiosyncratic), and values of 1 indicating that all deviations are due to technical inefficiencies. Value of gamma is also considered as explanatory power of the SFA model (equivalent to R2).

Following Battese and Coelli (1988, the technical efficiency of production for the ith firm at the $t$-th year is defined by equation (3),

$$
T E_{i t}=E\left\{-u_{i t} \mid \varepsilon_{i}\right\}
$$

where $\varepsilon_{\mathrm{i}}$ is the composite error term

The prediction of the technical efficiencies is based on its conditional expectation, given the model assumptions.

Following the above methodology, equation (1) is tax capacity estimates and equation (2) is tax inefficiency estimates.

\subsection{Conceptual Framework}

Being consumption based tax; tax base of Goods and Services Tax (GST) is dependent on consumption base of a state. In absence of representative annual consumption data for states, we have taken GSDP (GSVA at basic prices, current prices, 2011-12 series) as a proxy for consumption base. Collection of GST decreases with rising share of state's export in GSDP. Though inter-state transactions (both sales and consignment/ branch transfers) attract IGST, all input tax credits (ITC) against inter-state sales (or exports) are adjusted against IGST liability arising in the origin state. In the downstream of value chain IGST credits are adjusted against SGST, CGST and IGST liabilities in the destination state. Therefore in a destination based GST system, states having comparatively larger share of inter-state sales (as compared to domestic sales) are expected to collect lower GST revenue. The shift from origin to destination based tax system under the GST system results in larger erosion of tax base for 
exporting states. Prior to introduction of GST, inter-state sales used to attract origin based Central Sales Tax (CST) and due ITC used to be adjusted against CST liability. With introduction of GST, CST is subsumed under GST for commodities which are under the GST system (Mukherjee 2020). Prior to 1 July 2017, the data corresponding to revenue subsumed in GST includes CST revenue. Like GST regime, in the VAT regime also states having comparatively larger share of CST sales (as compared to domestic sales) are expected to collect lower VAT revenue, as applicable tax rates for VAT and CST sales differ.

In absence of state-wise figures of exports (both inter-state and international), we have taken relative share of mining, manufacturing (or industry) vis-à-vis agriculture to capture the state's potential to export.

We can present the framework as follows:

$$
\begin{aligned}
& \text { GST (or VAT) Revenue }=\mathrm{tC}-\mathrm{t}_{1} \mathrm{X} \\
& =t(G S D P-I-G-X+M)-t_{1} X \\
& =t G S D P-t A-X\left(t-t_{1}\right) \\
& =t G S D P-t A-f(\cdot)\left(t-t_{1}\right)
\end{aligned}
$$

Where,

$\mathrm{C}$ is the Private Final Consumption Expenditure

$\mathrm{X}$ is export

$t$ and $t_{1}$ are tax rates on consumption and export respectively

$\mathrm{I}$ is the investment

$\mathrm{G}$ is the Government Final Consumption Expenditure

$M$ is the import

$X=f\left(\frac{\text { mining }}{\text { agri }}, \frac{m f g}{\text { agri }}, \frac{\text { service }}{\text { agri }}\right)=f(\cdot)$

$A=I+G-M$

States which are forerunner in development ladder (as measured by per capita income) better placed in public goods delivery as compared low per capita income states. High income states enjoy economies of scale in the provision of public goods and services. Each rupee spent may result in better delivery of public goods and services in high income states as compared to low income states. In other words, unit cost of provisioning same level of public goods/ services is less for high income states as compared to low income states. Lack of peer pressure to improve achievement as well as efficiency in public goods delivery may be the factors which make high income states complacent with their existing level of expenditures and revenues. Being laggards in development ladder, less income states set their revenue targets aggressively to catch up with high income states in delivery of public goods and services. Therefore, needs for additional revenue generation may be less for high income states as compared to low income states. 
States located in difficult terrains, mainly hilly states and states where a large part of public expenditures is financed through central transfers (tax devolution and grants-in-aid) are expected to put lower efforts in own tax collection.

Given the paucity of long time series data and based on existing evidence in literature, we present the tax efficiency function as follows:

Tax Efficiency $=f($ per capita income of a state, minor state $)$

VAT Capacity Estimation:

$$
\begin{aligned}
& \text { Specification 1: Ingst }=\beta_{0}+\beta_{1} \text { lngsva }+\beta_{2} \text { mining_agri }+\beta_{3} m f g_{-} \text {agri }+\beta_{4} d u m_{-} g s t{ }^{*} \operatorname{lngsva} \\
& +\beta_{5} d u m_{-} g s t n+\beta_{6} d u m_{-} g s t+V_{i t}-U_{i t} \\
& \text { Specification 2: lngst }=\beta_{0}+\beta_{1} \text { Ingsva }+\beta_{2} \text { ind_agri }+\beta_{3} \text { serv_agri }+\beta_{4} d u m_{-} g s t n * \operatorname{lngsva}+ \\
& \beta_{5} d u m_{-} g s t n+\beta_{6} d u m \_g s t+V_{i t}-U_{i t}
\end{aligned}
$$

Where

$$
\begin{aligned}
& \text { Ingst Natural logarithm of State's revenue subsumed in GST or State } \\
& \text { GST collection (including IGST settlement) (in INR } 10 \text { million) } \\
& \text { Ingsva Natural logarithm of Gross State Value Added (in basic prices, } \\
& \text { current prices, 2011-12 series) (in Rs. } 0.1 \text { million) } \\
& \text { mining_agri Percentage share of mining \& quarrying vis-à-vis percentage } \\
& \text { share of agriculture (excluding forestry and logging, fishing } \\
& \text { and aquaculture) in GSVA } \\
& \text { mfg_agri Percentage share of manufacturing vis-à-vis agriculture in } \\
& \text { GSVA } \\
& \text { ind_agri Percentage share of industry (includes mining \& quarrying, } \\
& \text { manufacturing, electricity, gas, water supply \& other utility } \\
& \text { services, construction) vis-à-vis percentage share of } \\
& \text { agriculture in GSVA } \\
& \text { serv_agri Percentage share of services (excludes electricity, gas, water } \\
& \text { supply \& other utility services, construction) vis-à-vis } \\
& \text { percentage share of agriculture in GSVA } \\
& \text { dum_gstn } 1 \text { if the underlying GST data is sourced from GSTN database, } 0 \\
& \text { otherwise } \\
& \text { dum_gst Corresponds to introduction of GST in India. It takes value } 0.75 \\
& \text { for 2017-18, } 1 \text { for 2018-19 \& 2019-20, } 0 \text { otherwise }
\end{aligned}
$$

VAT Inefficiency Estimation:

Specification 1: $U_{i t}=\delta_{0}+\delta_{1} \ln p c g s v a+\delta_{2} d u m_{-}$minorstates $+W_{i t}$

Specification 2: $U_{i t}=\delta_{0}+\delta_{1} \operatorname{lnpcgsva}+\delta_{2} \operatorname{lnpcgsva2}+\delta_{3} d u m_{-}$minorstates $+W_{i t}$ 
Where
Inpcgsva
Natural logarithm of Per Capita Gross State Value Added (in basic prices, current prices, 2011-12 series) (in Rs.)
$\operatorname{lnpcgsva}{ }^{2}$ Square of Natural logarithm of Per Capita Gross State Value
dum_minorstates Added (in basic prices, current prices, 2011-12 series) (in Rs.) 1 for minor states (earlier special category cates, Delhi and Puducherry), 0 otherwise

We estimate maximum likelihood (ML) random-effects time-varying inefficiency effects model as developed by Battese and Coelli (1995) using sfpanel command in Stata (version 13.1) (as developed by Belotti et al. 2012). Battese and Coelli (1995) estimates parameters of the stochastic frontier and the inefficiency model simultaneously to avoid bias (Wang and Schmidt, 2002). This method captures time-varying inefficiency that reflects observable heterogeneity using maximum likelihood estimation technique.

Post estimation of the models, we estimate time variant tax efficiency across states by using methodology developed by Battese and Coelli (1988) using predict command in Stata (as developed by Belotti et al. 2012).

\section{Sources of Data and Constraints}

There are 29 states in India and two United Territories (UTs) with legislative assembly (Delhi and Puducherry). Out of 29 states, 11 states are used to be classified as Special Category States (SCS) earlier (Arunachal Pradesh, Assam, Himachal Pradesh, Jammu and Kashmir, Manipur, Meghalaya, Mizoram, Nagaland, Sikkim, Tripura and Uttarakhand). Other 18 states are known as General Category States. In our analysis we have classified 13 states as minor states (11 SCS, Delhi and Puducherry) and other 17 states as major states. We have clubbed data related to Telangana into Andhra Pradesh. We have introduced a dummy (dum_majorstates) which takes value 1 for major states and 0 otherwise to check the robustness of the estimated result.

Table 1 presents tax head-wise State taxes subsumed in GST. It shows that three taxes (state VAT, CST and entry tax) used to contribute 97 percent of states' revenue subsumed in GST.

Table 1: Category-wise States' Revenue Subsumed in GST as on 2015-16 (in INR 10 
million)

\begin{tabular}{|l|r|r|r|r|r|r|}
\hline \multicolumn{1}{|c|}{ State Taxes Subsumed in GST } & \multicolumn{1}{c|}{ All States } & \multicolumn{2}{c|}{ Major States } & \multicolumn{2}{c|}{ Minor States } \\
\hline State Value Added Tax (VAT) & $250,147.96$ & $(77.76)$ & $218,614.75$ & $(77.52)$ & $31,533.21$ & $(79.45)$ \\
\hline Central Sales Tax (CST) & $30,458.71$ & $(9.47)$ & $25,775.92$ & $(9.14)$ & $4,682.79$ & $(11.8)$ \\
\hline Works Contract & $2,997.48$ & $(0.93)$ & $1,322.37$ & $(0.47)$ & $1,675.11$ & $(4.22)$ \\
\hline Entertainment Tax & $2,099.09$ & $(0.65)$ & $1,992.21$ & $(0.71)$ & 106.88 & $(0.27)$ \\
\hline Lottery, Betting \& Gambling Tax & 455.47 & $(0.14)$ & 453.40 & $(0.16)$ & 2.06 & $(0.01)$ \\
\hline Luxury Tax & $1,847.58$ & $(0.57)$ & $1,745.25$ & $(0.62)$ & 102.33 & $(0.26)$ \\
\hline Entry Tax not in lieu of Octroi & $10,339.63$ & $(3.21)$ & $9,331.07$ & $(3.31)$ & $1,008.56$ & $(2.54)$ \\
\hline Entry Tax in lieu of Octroi/ Local & $20,181.02$ & $(6.27)$ & $20,175.14$ & $(7.15)$ & 5.88 & $(0.01)$ \\
\hline Body Tax & & & & & & \\
\hline Cesses \& Surcharges & 814.52 & $(0.25)$ & 698.31 & $(0.25)$ & 116.20 & $(0.29)$ \\
\hline Advertisement Tax & 208.50 & $(0.06)$ & 208.50 & $(0.07)$ & & $(0)$ \\
\hline Purchase Tax & 815.45 & $(0.25)$ & 803.52 & $(0.28)$ & 11.93 & $(0.03)$ \\
\hline ITC Reversal & $1,333.28$ & $(0.41)$ & 888.87 & $(0.32)$ & 444.40 & $(1.12)$ \\
\hline Sub-Total & $\mathbf{3 2 1 , 6 9 8 . 6 8}$ & $\mathbf{( 1 0 0 )}$ & $\mathbf{2 8 2 , 0 0 9 . 3 2}$ & $\mathbf{( 1 0 0 )}$ & $\mathbf{3 9 , 6 8 9 . 3 6}$ & $\mathbf{( 1 0 0 )}$ \\
\hline Arunachal Pradesh & 256.03 & & & & 256.03 & \\
\hline Gujarat & $28,856.39$ & & $28,856.39$ & & & \\
\hline Haryana & $15,230.59$ & & $15,230.59$ & & & \\
\hline Kerala & $16,821.37$ & & $16,821.37$ & & & \\
\hline Punjab & $14,471.77$ & & $14,471.77$ & & & \\
\hline Total & $\mathbf{3 9 7 , 3 3 4 . 8 3}$ & & $\mathbf{3 5 7 , 3 8 9 . 4 4}$ & {$[\mathbf{8 9 . 9 5}]$} & $\mathbf{3 9 , 9 4 5 . 3 9}$ & {$[\mathbf{1 0 . 0 5}]$} \\
\hline
\end{tabular}

Notes: *-Excludes Arunachal Pradesh, Gujarat, Haryana, Kerala \& Punjab, as tax head-wise revenue subsumed in GST figures are not available.

Figures in the parenthesis show the percentage share in sub-total

Figures in the bracket show the percentage share of total States' revenue subsumed in GST

Source: Compiled from various sources

\subsection{State GST Data}

Department of Revenue, Government of India has released state-wise revenue from taxes subsumed in GST for the period 2012-13 to 2017-18 (till 30 June 2017). However, for Arunachal Pradesh, Gujarat and Haryana the data is available only for 2015-16. We have estimated the revenue from taxes subsumed in GST for the three missing states for the period 2012-13 to 2014-15 and 2016-17 to 2017-18 (till 30 June 2017) based on data available from State Finance Accounts. For each of the missing states, the detailed process of estimation of revenue subsumed under GST is presented in Appendix Tables A.1 to A.3. To check the quality of the estimated series of GST for missing states, we have introduced a dummy (dum_missingstates) in our analysis. It takes value 1 for missing states and 0 otherwise.

GST Network (GSTN) has released state-wise GST collection for the period July 2017 to March 2020 and it is available in the public domain. To match the revenue of states corresponding to taxes subsumed under GST as available for the period 2012-13 to 2017-18 (till 30 June 2017), we have taken state GST (SGST) collection (without collection of GST 
compensation cess) and state-wise Integrated GST (IGST) settlement figures from GSTN data releases. The underlying rationale is that states are expected to collect the revenue corresponding to taxes subsumed in GST from SGST (including IGST settlement) with a projected annual growth rate in SGST collection (including IGST settlement) of 14 percent as prescribed in the Goods and Services (Compensation to States) Act, 2017. Central GST (CGST) collected from states does not constitute tax revenue of states. States receive a share of net collection of CGST (net of refunds and costs of collection) from the union governments as per the tax devolution formula of the Finance Commission. IGST collected from states constitutes the credit-in-transition which is eventually adjusted against tax liability (either in IGST or CGST-cum-SGST) arising in downstream of value chains in the state of destination. States receive IGST settlement (after adjustment of input tax credit against IGST and /or CGST-cumSGST arising in the state) against inter-state imports of goods and services from the union government. For a state where predominantly domestic consumptions are met through imports of goods and services from other states, the IGST settlement amount will be higher than IGST collection from the state.

In addition to IGST settlement, states also receive IGST transfers from the union government where IGST is collected from overseas imports/exports of goods and services and domestic supply of goods and services where Place of Supply (POS) information are not available, i.e., Business-to-Consumer (B2C) transactions through e-commerce where transaction value is less than INR 0.25 million. Since this transfer is tax-devolution in nature and actual amount of receipts by states is not available in the public domain, we have not incorporated this component in our analysis.

In the GST system, tax payers adjust all available input tax credits (ITCs) in making tax payments and the balance amount of tax liability is paid in cash. Therefore the IGST settlement that states receive are net revenue for states. The union government is empowered to collect and settle IGST and it is the responsibility of the union government to accommodate ITC adjustment demands against available IGST credit as and when it arises in downstream of the value chain. Therefore, the states receive the IGST settlement from the union government after adjustment of available IGST credit. However, any excess or short payment of IGST settlement is adjusted with states over the next round's (month's) settlement.

GST compensation cess (GSTCC) is collected from certain listed goods (predominantly from luxury and 'sin' goods) to compensate states during the GST transition period (i.e., from 1 July 2017 to 30 June 2022) for the revenue loss on account of introduction of GST. For each state, the revenue loss is estimated by the difference between actual collection of SGST (including IGST settlement) and projected collection of revenue subsumed in GST. During the GST transition period, for each state and for each financial year, the projected GST collection is based on 14 percent annual growth rate in net revenue which is subsumed in GST in the base year 2015-16. 


\subsubsection{Finance Account Data vs. GSTN Data}

State Finance Accounts (FAs) are another data source of GST. State FAs provide audited financial statements of state governments in India. However, FAs come with an average time lag of 2 to 3 years. For example, 2017-18 FAs are available online for majority of states, except for Jammu and Kashmir, Jharkhand and Goa. Moreover, for financial details of united territories with legislative assembly, those are Delhi and Puducherry; one has to rely on 'Combined Finance and Revenue Accounts - Union and States' which is released with an average time lag of 3 to 4 years. State-wise GST collection figures are available from FAs of 2017-18 for the period July 2017 to March 2018. To test if there is any over or under accounting of revenue on account of state GST collection between two data sources - GSTN and Finance Accounts - we have compared the data series. We found that for majority of states, SGST data reported in Finance Account (under heading 0006) is higher than SGST collection (including IGST settlement) reported by the GSTN. Being an audited statement of accounts, we have taken SGST collection figures from FAs for 2017-18 for states where information is available. Since FAs for 2018-19 and 2019-20 are not available yet, we have relied on GSTN data. In absence of FAs of Jharkhand and Goa, we have taken SGST collection figures from budget documents of the respective state governments. Therefore, for three states (Delhi, Jammu and Kashmir and Puducherry) in 2017-18 and all states for 2018-19 and 2019-20, we have relied on GSTN data of SGST. We have created a dummy for GSTN data source (dum_gstn) in our analysis where it takes value 1 for states and years where GSTN data is used, 0 otherwise.

To estimate tax efficiency of Central GST (CGST) collection across states in India, we need pre-GST state-wise tax collection on account central Value Added Tax (CENVAT) and services tax. However, the same information is not available at the state level. Tax jurisdictions of the central tax authority may not necessarily map into state administrative boundary, and therefore taxes collected at the commissionerate level by Central Board of Indirect Taxes and Customs do not necessarily correspond to the state where the commissionerate is located.

\subsection{State GSVA Data}

According to 2011-12 series of 'Domestic Product of States in India', Gross State Value Added (GSVA) (at basic prices) is equivalent to Gross State Domestic Product (GSDP) at factor costs as available for the earlier series. We have taken state-wise GSVA (at basic prices, current prices) from the Ministry of Statistics and Programme Implementation website (http://www.mospi.gov.in/GSVA-NSVA) as released on 15 March 2020. Except Maharashtra, for all other states GSVA data is available for the period 2011-12 to 2018-19. Out of 30 states, for 2019-20 GSVA is available for Delhi, Haryana, Himachal Pradesh, Karnataka, Madhya Pradesh, Meghalaya, Mizoram, Odisha, Puducherry, Rajasthan, Tamil Nadu, Uttar Pradesh. 
For States where GSVA figures are not available for 2019-20 (for Maharashtra 2018-19 and 2019-20), we have extrapolated GSVA by taking average growth rate of GSVA of the state in preceding last three years. For estimation of sectoral composition of GSVA, we have extrapolated the sectoral GSVA by taking average share in GSVA in proceeding last three years of the state and applying it to estimated GSVA for the missing year(s). Since such extrapolation may not reflect actual growth scenario of a state, we have restricted number of observations till 2018-19 in one of the SFA models to test robustness of the estimated model with reference to restriction in the number of time series observations.

\section{Results and Discussion}

The results show that apart from scale of economic activity of a state (as measured by lngsva), structural composition of the economy (as measured by ratio of shares of mining, manufacturing, industry and services in GSVA vis-à-vis share of agriculture in GSVA) is important factor in determining the capacity of GST collection (Table 3). We found that structure of the economy significantly influences scale of economic activity of the states and therefore to avoid the problem of multicollinearity we have taken share of mining, manufacturing (or industry) and services vis-à-vis agriculture in GSVA in the SFA models. Results show that states having higher share in mining and quarrying vis-à-vis agriculture in GSVA have lower GST capacity. This phenomenon has some bearing with the natural resource curse hypothesis - countries or states with higher endowment of natural resources are likely to have less economic growth; an economy's tax base is influenced positively by its size (as measured by GSVA) and growth rate of GSVA. States rich in mineral resources are unable to use that wealth to boost their economy and, counter-intuitively, experience lower economic growth than countries without an abundance of natural resources. Moreover, state where minerals (both metallic and non-metallic) are extracted not necessarily having processing capacity or manufacturing facilities and therefore explored ores often used to be exported out of the state. So subsequent value additions are captured in states where manufacturing facilities or metallurgical industries are located. Therefore, erosion of tax base of minerals rich states is a design problem of the GST regime. This problem may be addressed by careful design of inter-governmental fiscal transfer system. Share of manufacturing in GSVA vis-à-vis agriculture has positive relationship with GST capacity. This is in contrary to findings of earlier study with respect to VAT efficiency across Indian states (Mukherjee 2019). States where manufacturing value addition is higher than agriculture, it is expected that per capita income would be higher and therefore higher consumption base. However, higher manufacturing base does not necessarily imply GST base would be high. It depends on relative size of domestic sales (consumption) vis-à-vis inter-state sales (or exports). For example, in Himachal Pradesh and Uttarakhand manufacturing bases are high but a large part of manufactured products are exported out of the state to cater all India market. Also, realization of value addition in terms of wages and salaries are not necessarily consumed in the state but spill over to neighboring states. This is especially a case for states where manufacturing facilities are located adjacent to advanced states in terms of social and physical infrastructures. Like manufacturing, share of industry in GSVA vis-à-vis agriculture 
has positive impact on GST capacity. In addition to mining and manufacturing, industry sector includes electricity, gas and water supply and constructions. The result implies that states having larger share of industry in GSVA vis-à-vis agriculture also have larger GST capacity. Share of services in GSVA vis-à-vis agriculture has negative impact on GST capacity. This is again in contrary to findings of earlier study on state VAT efficiency (Mukherjee 2019). The results show that as compared to the VAT regime, tax base of states in the GST regime has structurally changed and availability of more time series data points may strengthen this finding.

To address the change in tax base with introduction of GST and corresponding change in the revenue corresponding to GST, we have introduced a dummy (dum_gst) in the SFA models. The results show that dum_gst has negative impact (in intercept) on GST capacity. We have not found any impact of $d u m_{-} g s t$ on slope coefficient of the estimated capacity function. The result implies that introduction of GST has an impact on tax capacity of states and the impact is restricted to scale (intercept) effect.

To check the impact of change in data source of underlying GST data, we have introduced a dummy (dum_gstn) for states and years where GST data is sourced from GSTN database. The results show that dum_gstn has positive intercept effect but negative slope effect in the capacity function. This implies that keeping all other variables at their levels, data corresponding to GSTN shows lower capacity beyond a point of lngsva. Alternatively, for low GSVA states GSTN data shows higher capacity but for high GSVA states it shows lower capacity. Harmonization of GST databases is desirable along with stabilization of the GST.

We also introduced time dummies to capture trends in the capacity function, but did not find any significant impact.

Results of inefficiency function show that high per capita income (as measured by per capita GSVA) states have lower tax efficiency as compared to low income states. Tax efficiency declines with rising per capita income but it rises after a point. This implies that there is a nonlinear relationship between per capita income and tax efficiency. With rising per capita income of a state, tax collection increases and which makes the state complacent. But with further rise in per capita income, states may face revenue crunch to meet people expectation and therefore tax efficiency improves. Tax efficiencies of minor states are lower as compared to major states and this finding is in line with our expectation. We have not found any significant impacts of $d u m_{-} g s t$ and $d u m_{-}$gstn in inefficiency function.

Table 2: Estimated Results of GST Capacity and GST Efficiency

\begin{tabular}{|c|c|c|c|c|c|c|c|c|c|}
\hline & \multicolumn{3}{|c|}{ Model I } & \multicolumn{3}{|c|}{ Model II } & \multicolumn{3}{|c|}{ Model III } \\
\hline Stochastic Frontier & Coefficient & & StdError & Coefficient & & StdError & Coefficient & & StdError \\
\hline lngsva & 1.094 & $* * *$ & 0.019 & 1.078 & $* * *$ & 0.021 & 0.926 & $* * *$ & 0.032 \\
\hline dum_gstn*lngsva & -0.119 & $* * *$ & 0.029 & -0.116 & $* * *$ & 0.029 & -0.095 & *** & 0.028 \\
\hline
\end{tabular}




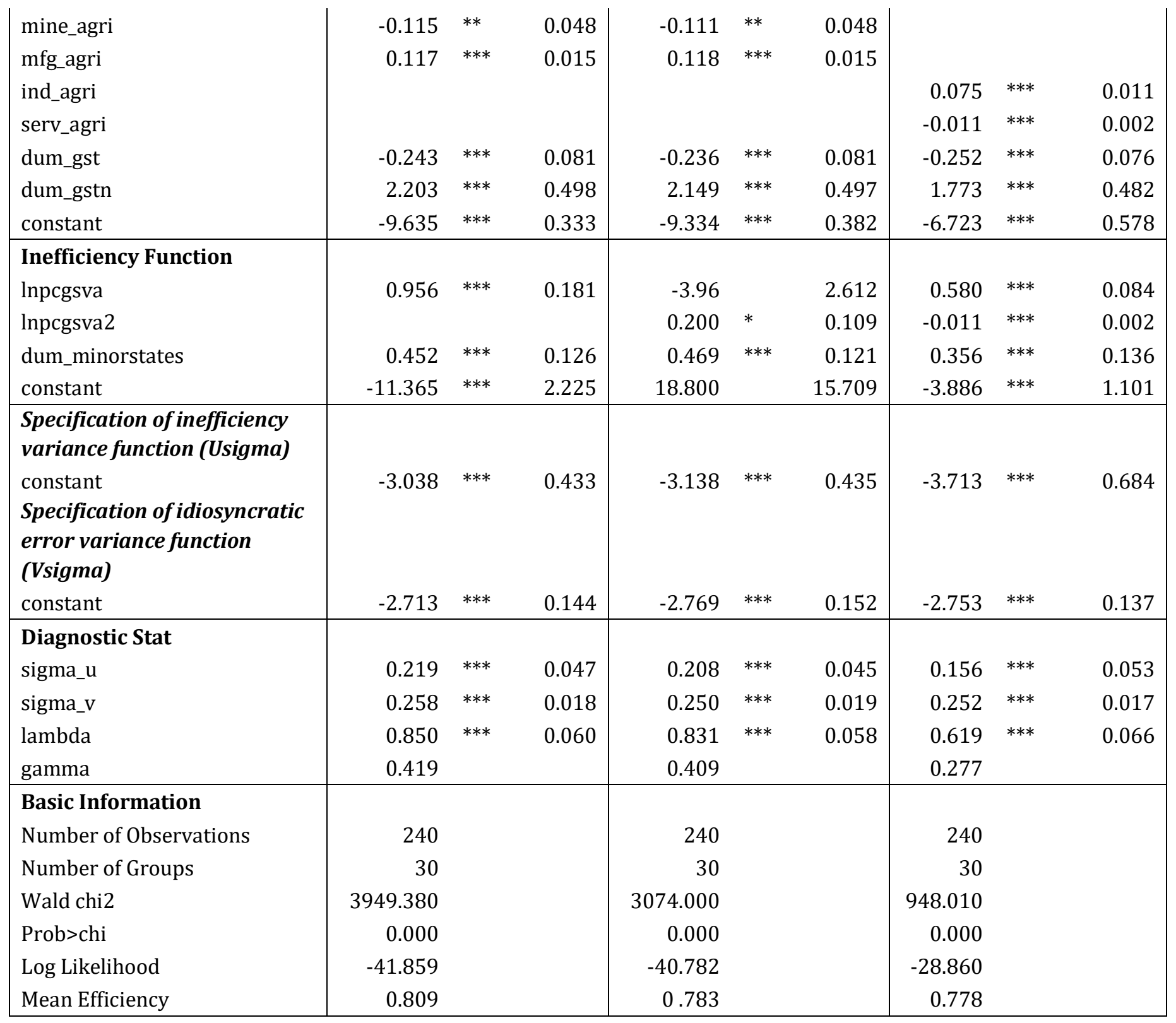

Notes: ${ }^{* * *},{ }^{* *}$ and ${ }^{*}$ imply estimated $\mathrm{z}$-statistics are significant at $0.01,0.05$ and 0.10 level respectively

Among three alternative models estimated in Table 2, we have selected Model I for analysis of tax efficiency. The selection is based on estimated value of gamma which is the highest for Model I. Table 3 shows that except Arunachal Pradesh and Mizoram, GST efficiencies of all states have gone down post 2017-18. Among major states, maximum fall in tax efficiency is observed for Goa, followed by Karnataka, Kerala and Andhra Pradesh (including Telangana). Among minor states, maximum fall in tax efficiency is observed for Puducherry, followed by Delhi, Himachal Pradesh and Sikkim. Average tax efficiency is lower for minor states as compared to major states for all the periods. For major states, the highest 


\section{Working Paper No. 310}

tax efficiency is observed for Bihar, followed by West Bengal and Uttar Pradesh. For minor states, the highest tax efficiency is observed for Jammu \& Kashmir, followed by Tripura and Assam. Table 3 shows that for major states, relatively low income states have higher tax efficiency as compared to high income states.

Table 3: State-wise Average GST Efficiency over the Period (in percent)

\begin{tabular}{|c|c|c|c|c|c|}
\hline \multirow[t]{2}{*}{ State } & \multicolumn{2}{|c|}{$\begin{array}{c}\text { Average }(2012-13 \text { to } 2016- \\
17)(A)\end{array}$} & \multicolumn{2}{|c|}{$\begin{array}{c}\text { Average }(2017-18 \text { to } 2019- \\
20)(B)\end{array}$} & \multirow[t]{2}{*}{$\begin{array}{l}\text { \% Change (C) } \\
{\left[(\mathrm{B}-\mathrm{A}) / \mathrm{A}^{*} 100\right]}\end{array}$} \\
\hline & Tax Efficiency & Rank & Tax Efficiency & Rank & \\
\hline Andhra Pradesh* & 0.89 & $(12)$ & 0.80 & (13) & 10.1 \\
\hline Bihar & 0.97 & (1) & 0.96 & $(1)$ & 1.3 \\
\hline Chhattisgarh & 0.94 & (7) & 0.90 & (8) & 4.3 \\
\hline Goa & 0.54 & (17) & 0.32 & (17) & 41.2 \\
\hline Gujarat & 0.93 & (9) & 0.90 & (9) & 3.5 \\
\hline Haryana & 0.93 & $(10)$ & 0.91 & (6) & 1.8 \\
\hline Jharkhand & 0.96 & $(4)$ & 0.94 & (4) & 2.0 \\
\hline Karnataka & 0.88 & (13) & 0.65 & (16) & 26.1 \\
\hline Kerala & 0.87 & (14) & 0.75 & (14) & 13.8 \\
\hline Madhya Pradesh & 0.95 & $(6)$ & 0.91 & (7) & 4.5 \\
\hline Maharashtra & 0.86 & (15) & 0.81 & (12) & 6.1 \\
\hline Odisha & 0.95 & (5) & 0.91 & (5) & 3.9 \\
\hline Punjab & 0.93 & $(8)$ & 0.84 & (11) & 10.2 \\
\hline Rajasthan & 0.92 & (11) & 0.88 & (10) & 4.4 \\
\hline Tamil Nadu & 0.82 & (16) & 0.72 & (15) & 12.2 \\
\hline Uttar Pradesh & 0.96 & (3) & 0.95 & (3) & 1.1 \\
\hline West Bengal & 0.96 & (2) & 0.95 & (2) & 0.8 \\
\hline Major States & 0.90 & & 0.83 & & 7.7 \\
\hline Arunachal Pradesh & 0.71 & [11] & 0.74 & [7] & -5.3 \\
\hline Assam & 0.92 & [3] & 0.85 & [5] & 8.2 \\
\hline Delhi & 0.42 & [12] & 0.30 & [12] & 29.6 \\
\hline Himachal Pradesh & 0.72 & {$[8]$} & 0.50 & [10] & 29.7 \\
\hline Jammu and Kashmir & 0.96 & [1] & 0.95 & {$[1]$} & 1.3 \\
\hline Manipur & 0.92 & [4] & 0.89 & [3] & 4.0 \\
\hline Meghalaya & 0.88 & [5] & 0.83 & [6] & 5.3 \\
\hline Mizoram & 0.85 & [6] & 0.87 & [4] & -1.6 \\
\hline Nagaland & 0.76 & {$[7]$} & 0.65 & [8] & 15.2 \\
\hline Puducherry & 0.71 & [10] & 0.37 & [11] & 47.2 \\
\hline Sikkim & 0.39 & [13] & 0.28 & [13] & 29.0 \\
\hline Tripura & 0.94 & {$[2]$} & 0.90 & [2] & 4.6 \\
\hline Uttarakhand & 0.71 & [9] & 0.61 & [9] & 14.0 \\
\hline Minor States & 0.76 & & 0.67 & & 11.7 \\
\hline All States & 0.84 & & 0.76 & & 9.3 \\
\hline
\end{tabular}

Note: *-includes Telangana

Source: Computed 
Average GST efficiency shows falling trends for both major and minor states (Figure 1). Improving tax efficiency would be a challenge in the GST regime. Gap between average GST efficiency of major and minor states is another area of concern, as the gap has further gone up during 2018-20.

\section{Figure 1: Temporal Variation in Average GST Efficiency}

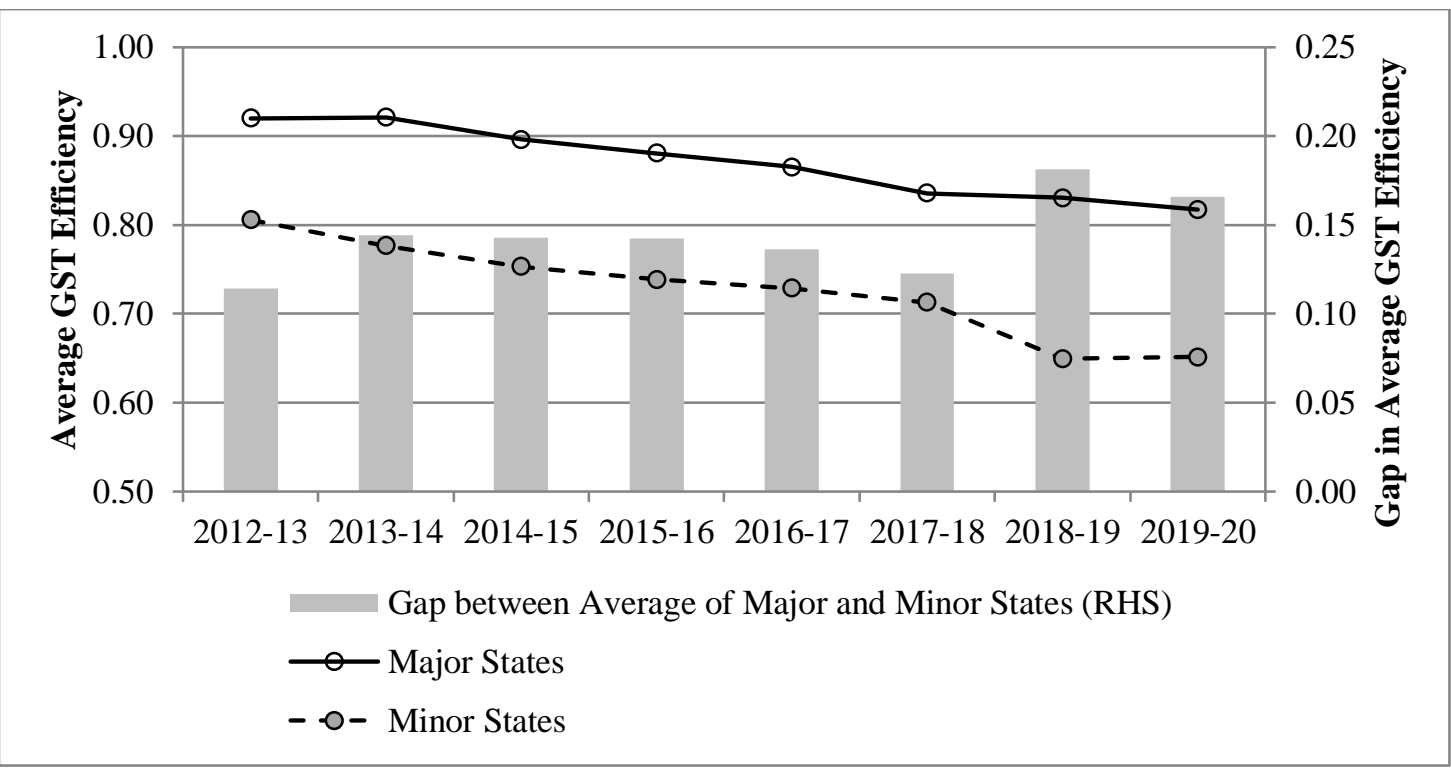

Source: Computed

\subsection{Robustness Check}

To check whether the estimated Model I is sensitive to underlying data, we estimate three alternative models by restricting number of states to only - a) those where GST data is available for the period (2012-13 to 2017-18) in the public domain (Model IV), b) major states (Model V) and restricting time periods till 2018-19 (Model VI). The results show that excluding missing states from the analysis (in Model IV) results in fall in explanatory power of the Model I substantially. Being important states, excluding Gujarat and Haryana from the analysis may not be appropriate, so we have avoided it. By restricting the analysis to only major states (in Model V), explanatory power of the Model I improves substantially (gamma value increases from 0.419 to 0.865 ) and also the differences in data sources (as captured through dum_gstn) do not show any significant impact on either intercept or slope coefficients of the capacity function. Model V could be an alternative model for estimation of tax efficiency for major states. However, separate SFA model for minor states do not withstand due to short panel - small number of cross-sectional observations (number of minor states is 13) and for only 8 years of time series observations. By restricting the period of analysis upto 2018-19 (in Model VI), the explanatory power of the estimated Model I improves only marginally. Therefore, we select Model I for GST gap analysis. 


\section{Working Paper No. 310}

Table 3: Estimated Results of GST Capacity and GST Efficiency with Data Restrictions

\begin{tabular}{|c|c|c|c|c|c|c|c|c|c|}
\hline \multirow[b]{2}{*}{ Stochastic Frontier } & \multicolumn{3}{|c|}{$\begin{array}{c}\text { Model IV } \\
\text { Without Missing States } \\
\text { (dum_missingstates }=0 \text { ) }\end{array}$} & \multicolumn{3}{|c|}{$\begin{array}{c}\text { Model V } \\
\text { Only Major States } \\
(\text { dum_majorstates }=1)\end{array}$} & \multicolumn{3}{|c|}{$\begin{array}{c}\text { Model VI } \\
\text { for 2012-13 to 2018-19 } \\
\text { (if year<8) }\end{array}$} \\
\hline & Coefficient & & StdError & Coefficient & & StdError & Coefficient & & StdError \\
\hline lngsva & 1.112 & *** & 0.015 & 0.901 & $* * *$ & 0.036 & 1.093 & $* * *$ & 0.020 \\
\hline dum_gstn*Ingsva & -0.077 & $* * *$ & 0.029 & 0.073 & & 0.058 & -0.102 & $* * *$ & 0.038 \\
\hline mine_agri & -0.144 & $* * *$ & 0.045 & -0.411 & $* * *$ & 0.096 & -0.131 & $* *$ & 0.051 \\
\hline mfg_agri & 0.104 & $* * *$ & 0.014 & 0.189 & $* * *$ & 0.046 & 0.135 & $* * *$ & 0.017 \\
\hline dum_gst & -0.324 & $* * *$ & 0.086 & -0.243 & $* * *$ & 0.066 & -0.227 & $* * *$ & 0.083 \\
\hline dum_gstn & 1.527 & $* * *$ & 0.507 & -1.241 & & 1.043 & 1.864 & $* * *$ & 0.651 \\
\hline constant & -9.950 & $* * *$ & 0.251 & -6.238 & $* * *$ & 0.635 & -9.615 & $* * *$ & 0.365 \\
\hline \multicolumn{10}{|l|}{ Inefficiency Function } \\
\hline lnpcgsva & 0.783 & $* * *$ & 0.161 & 2.886 & $* * *$ & 1.010 & 1.051 & $* * *$ & 0.212 \\
\hline dum_minorstates & & & & & & & 0.438 & $* * *$ & 0.135 \\
\hline constant & -9.084 & $* * *$ & 1.953 & -35.043 & $* * *$ & 12.450 & -12.408 & $* * *$ & 2.582 \\
\hline \multicolumn{10}{|l|}{$\begin{array}{l}\text { Specification of inefficiency } \\
\text { variance function (Usigma) }\end{array}$} \\
\hline constant & -3.891 & $* * *$ & 0.672 & -1.924 & $* * *$ & 0.725 & -2.933 & $* * *$ & 0.430 \\
\hline \multicolumn{10}{|l|}{$\begin{array}{l}\text { Specification of idiosyncratic } \\
\text { error variance function } \\
\text { (Vsigma) }\end{array}$} \\
\hline constant & -2.615 & $* * *$ & 0.122 & -3.787 & $* * *$ & 0.246 & -2.704 & $* * *$ & 0.157 \\
\hline \multicolumn{10}{|l|}{ Diagnostic Stat } \\
\hline sigma_u & 0.143 & $* * *$ & 0.048 & 0.382 & $* * *$ & 0.139 & 0.231 & $* * *$ & 0.050 \\
\hline sigma_v & 0.271 & $* * *$ & 0.017 & 0.151 & $* * *$ & 0.019 & 0.259 & $* * *$ & 0.020 \\
\hline lambda & 0.528 & $* * *$ & 0.058 & 2.538 & $* * *$ & 0.153 & 0.892 & $* * *$ & 0.063 \\
\hline gamma & 0.218 & & & 0.865 & & & 0.443 & & \\
\hline \multicolumn{10}{|l|}{ Basic Information } \\
\hline Number of Observations & 216 & & & 216 & & & 210 & & \\
\hline Number of Groups & 27 & & & 27 & & & 30 & & \\
\hline Wald chi2 & 6753.060 & & & 6753.060 & & & 3178 & & \\
\hline Prob>chi & 0.000 & & & 0.000 & & & 0.000 & & \\
\hline Log Likelihood & -35.025 & & & -35.025 & & & -39.905 & & \\
\hline Mean Efficiency & 0.841 & & & 0.769 & & & 0.788 & & \\
\hline
\end{tabular}

Notes: ${ }^{* * *},{ }^{* *}$ and ${ }^{*}$ imply estimated $\mathrm{z}$-statistics are significant at $0.01,0.05$ and 0.10 level respectively

\subsection{Estimation of GST Gap}

Based on estimated tax efficiency across states, an attempt is made to estimate the 
potential GST collection (as \% of GSVA) that a state could achieve by raising tax efficiency to a level which is the maximum tax efficiency that has achieved by a state (among respective category of states) in a particular year during the period of analysis.

The process of estimation of average GST gap is presented as follows:

$$
\operatorname{PGST}_{i}=\frac{1}{n} \sum_{j \mid i}\left[\frac{\left\{G S T_{i j}+\left(G S T E_{m j}-G S T E_{i j}\right) *\left(\frac{G S T_{i j}}{G S T E_{i j}}\right)\right\}}{G S V A_{i j}} * 100\right]
$$

Where,

$\mathrm{GSTE}_{\mathrm{ij}}$ is the GST efficiency of the ith state in the jth year

GSTE $_{\mathrm{mj}}$ is the maximum GST efficiency that has achieved by a state (among the respective category of states) in the jth year

$\mathrm{GST}_{\mathrm{ij}}$ is the collection of GST in the ith state for the jth year

$\mathrm{GSVA}_{\mathrm{ij}}$ is the gross state value added (at basic prices, current prices, 2011-12 series) for the ith state and jth year

$\mathrm{PGST}_{\mathrm{i}}$ is the average potential GST collection (as \% of GSVA) for the ith state, if the state achieves tax efficiency to the level equivalent to maximum tax efficiency that has achieved by a state (among the respective category of states) for a year

$\mathrm{n}$ is the number of years of our analysis $(n=8)$

Since, tax efficiency of minor states are lower than major states, we have estimated GST gap separately for minor states. Figure 2 shows that among major states, if Goa increases tax efficiency it could generate another 5 percent of GSVA as GST revenue. On average major states could increase 0.52 percent of GSVA by increasing their tax efficiency. 
Figure 2: Major-State-wise Average Potential and Actual GST Collection (Average over 2012-13 to 2019-20)

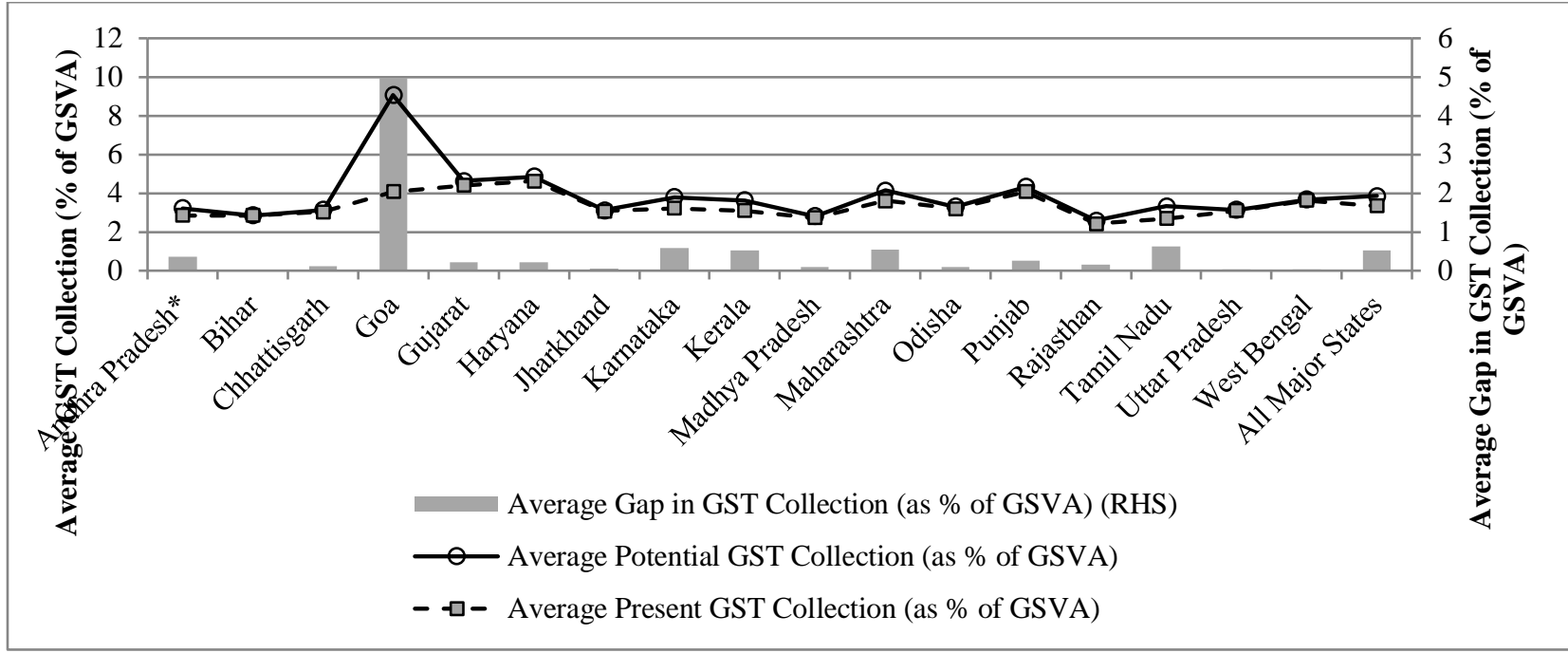

Source: Computed

Among major states, if Delhi increases tax efficiency it could generate another 5 percent of GSVA as GST revenue (Figure 3). Sikkim, Puducherry and Himachal Pradesh could increase their GST revenue by 2.7 percent, 2.5 percent and 1.4 percent of GSVA respectively. On average minor states could increase their GST revenue by 1.15 percent of GSVA.

Figure 3: Minor-State-wise Average Potential and Actual GST Collection (Average over 2012-13 to 2019-20)

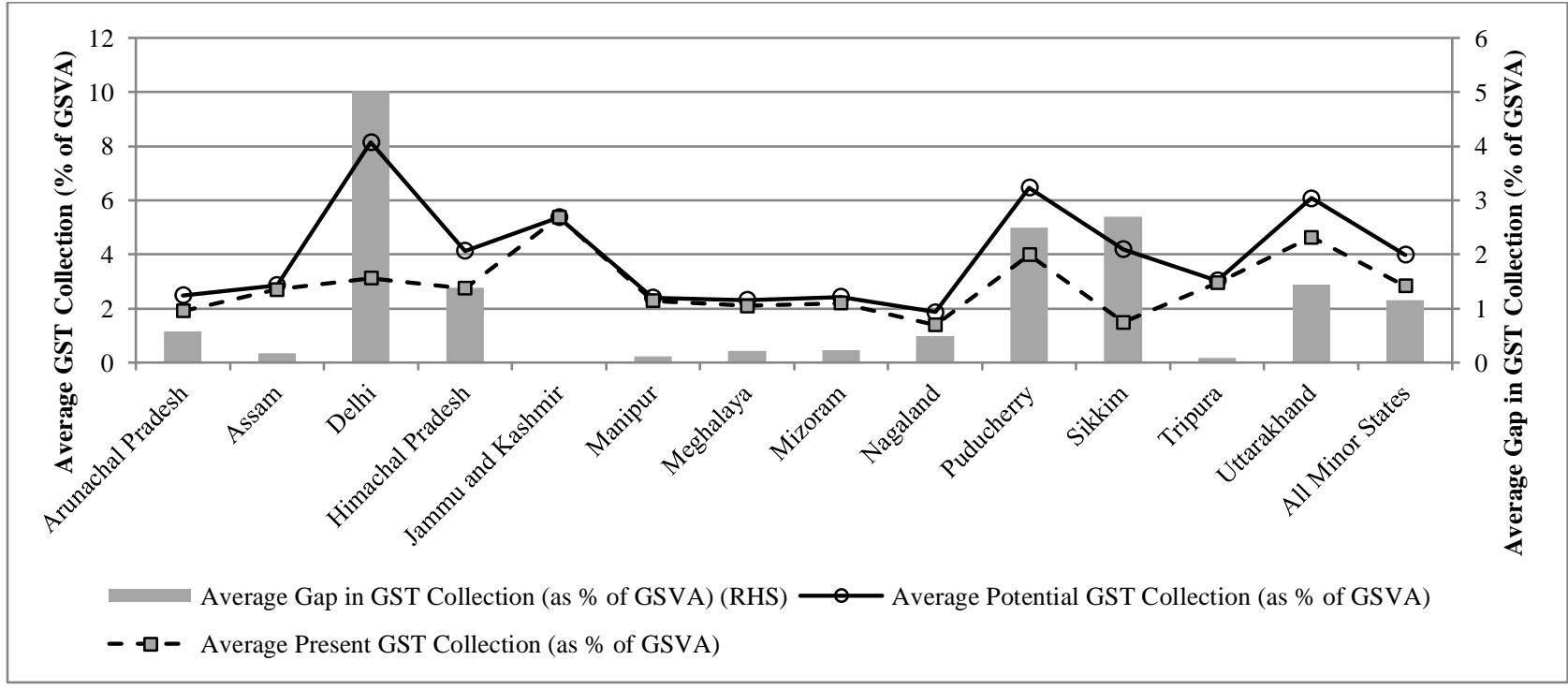

Source: Computed

Figure 4 shows that for major states, the gap in GST collection (as \% of GSVA) is increasing since 2014-15, except in 2017-18. 
Figure 4: Annual Average Potential and Actual GST Collection across Major States (Average over 2012-13 to 2019-20)

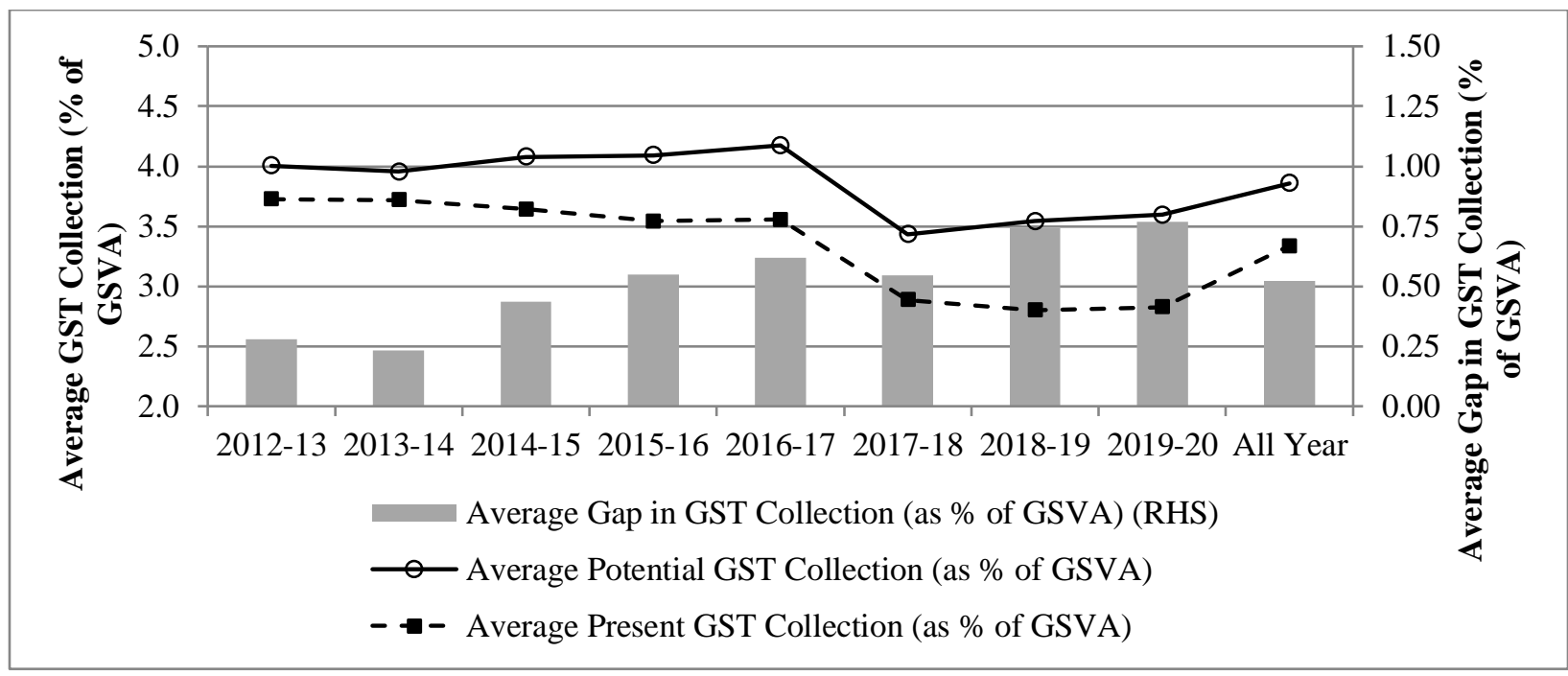

Source: Computed

Figure 5 shows that for minor states, gap in GST collection has increased continuously since 2012-13, except in 2017-18. Improving tax efficiency is desirable given the rising revenue needs of these states.

Figure 5: Annual Average Potential and Actual GST Collection across Minor States (Average over 2012-13 to 2019-20)

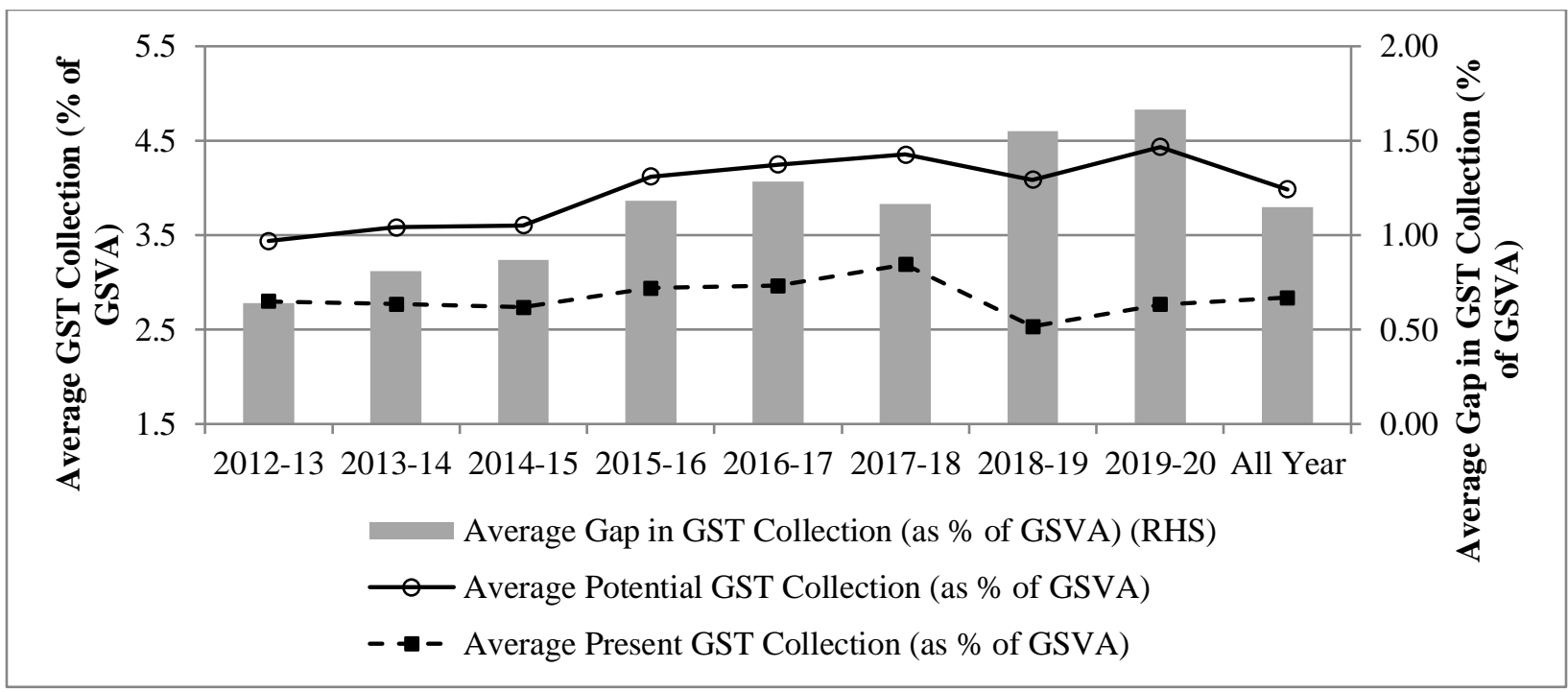

Source: Computed

\section{Conclusions}


The results show that apart from scale of economic activity of a state (as measured by lngsva), structural composition of the economy (as measured by ratio of shares of mining, manufacturing, industry and services in GSVA vis-à-vis share of agriculture in GSVA) is important factor in determining the capacity of GST collection. Results show that states having higher share in mining and quarrying vis-à-vis agriculture in GSVA have lower GST capacity. This phenomenon has some bearing with the natural resource curse hypothesiscountries or states with higher endowment of natural resources are likely to have less economic growth; an economy's tax base is influenced positively by its size (as measured by GSVA) and growth rate of GSVA. States rich in mineral resources are unable to use that wealth to boost their economy and, counter-intuitively, experience lower economic growth than countries without an abundance of natural resources (Auty 1993). Moreover, state where minerals (both metallic and non-metallic) are extracted not necessarily having processing capacity or manufacturing facilities and therefore explored ores often used to be exported out of the state. So subsequent value additions are captured in states where manufacturing facilities or metallurgical industries are located. Therefore, erosion of tax base of minerals rich states is a design problem of the GST regime. This problem may be addressed by careful design of inter-governmental fiscal transfer system. Share of manufacturing in GSVA vis-à-vis agriculture has positive relationship with GST capacity. States where manufacturing value addition is higher than agriculture, it is expected that per capita income would be higher and therefore higher consumption base. However, higher manufacturing base does not necessarily imply GST base would be high. It depends on relative size of domestic sales (consumption) vis-à-vis inter-state sales (or exports). For example, in Himachal Pradesh and Uttarakhand manufacturing bases are high but a large part of manufactured products are exported out of the state to cater all India market. Also, realization of value addition in terms of wages and salaries are not necessarily consumed in the state but spill over to neighboring states. This is especially a case for states where manufacturing facilities are located adjacent to advanced states in terms of social and physical infrastructure. Like manufacturing, share of industry in GSVA vis-à-vis agriculture has positive impact on GST capacity. In addition to mining and manufacturing, industry sector includes electricity, gas and water supply and constructions. The result implies that states having larger share of industry in GSVA vis-à-vis agriculture also have larger GST capacity. Share of services in GSVA vis-à-vis agriculture has negative impact on GST capacity. The results show that as compared to the VAT regime, tax base of states in the GST regime has structurally changed and availability of more time series data points may strengthen this finding.

To address the change in tax base with introduction of GST and corresponding change in the revenue corresponding to GST, we have introduced a dummy (dum_gst) in the SFA models. The results show that dum_gst has negative impact (in intercept) on GST capacity. We have not found any impact of $d u m_{-}$gst on slope coefficient of the estimated capacity function. The result implies that introduction of GST has an impact on tax capacity of states and the impact is restricted to scale (intercept) effect. 
To check the impact of change in data source of underlying GST data, we have introduced a dummy (dum_gstn) for states and years where GST data is sourced from GSTN database. The results show that dum_gstn has positive intercept effect but negative slope effect in the capacity function. This implies that keeping all other variables at their levels, data corresponding to GSTN shows lower capacity beyond a point of lngsva. Alternatively, for low GSVA states GSTN data shows higher capacity but for high GSVA states it shows lower capacity. Harmonization of GST database sources is desirable along with stabilization of the GST.

Results of inefficiency function show that high per capita income (as measured by per capita GSVA) states have lower tax efficiency as compared to low income states. Tax efficiency declines with rising per capita income but it rises after a point. This implies that there is a nonlinear relationship between per capita income and tax efficiency. With rising per capita income of a state, tax collection increases and which make the state complacent. But with further rise in per capita income states may face revenue crunch to meet people expectation and therefore tax efficiency improves. Tax efficiencies of minor states are lower as compared to major states and this finding is in line with our expectation. We have not found any significant impacts of $d u m_{-} g s t$ and $d u m_{-} g s t n$ in inefficiency function. 


\section{References}

Auty, Richard M. (1993), "Sustaining Development in Mineral Economies: The resource curse thesis", Routledge, London and New York.

Bahl, R. W. (1972), “A Representative Tax System Approach to Measuring Tax Effort in Developing Countries", IMF Staff Papers, 19(1): 87-124.

Battese, G. E., and T. J. Coelli. (1995), "A model for technical inefficiency effects in a stochastic frontier production function for panel data”, Empirical Economics, 20: 325-332.

Battese, G. E., and T. J. Coelli (1988), "Prediction of firm-level technical efficiencies with a generalized frontier production function and panel data", Journal of Econometrics, 38: 387-399.

Belotti, Federico, Silvio Daidone, Giuseppe Ilardi and Vincenzo Atella (2012), "Stochastic frontier analysis using Stata", Research Paper Series, 10(12), No. 251, Centre for Economic and International Studies. Available at: http://papers.ssrn.com/paper.taf?abstract_id=2145803 (last accessed on 22 January 2018).

Bird, Richard M., Jorge Martinez-Vazquez, Benno Torgler (2008), "Tax Effort in Developing Countries and High Income Countries: The Impact of Corruption, Voice and Accountability", Economic Analysis \& Policy, 38(1): 55-71.

Brun J.-F. and M. Diakité (2016) "Tax Potential and Tax Effort: An Empirical Estimation for Non-resource Tax Revenue and VAT's Revenue", Études et Documents, no 10, CERDI. http://cerdi.org/production/show/id/1814/type_production_id/1 (last accessed on 23 January 2018).

Coondoo, Dipankor, Amita Majumder, Robin Mukherjee and Chiranjib Neogi (2001), "Relative Tax Performances: Analysis for Selected States in India", Economic Research Unit, Indian Statistical Institute, Calcutta.

Cyan, Muharraf, Jorge Martinez-Vazquez and Violeta Vulovic (2013), "Measuring tax effort: Does the estimation approach matter and should effort be linked to expenditure goals?", ICEPP Working Papers 39, International Center for Public Policy. Available at: https://scholarworks.gsu.edu/icepp/39 (last accessed on 9 July 2020).

Davoodi, Hamid R. and David A. Grigorian (2007), "Tax Potential vs. Tax Effort: A CrossCountry Analysis of Armenia's Stubbornly Low Tax Collection", WP/07/106, IMF Working Paper, May 2007. International Monetary Fund, Washington D.C., USA.

Fenochietto, Ricardo and Carola Pessino (2013), "Understanding Countries' Tax Effort", IMF Working Paper No. WP/13/244, Fiscal Affairs Department, International Monetary Fund, Washington, D.C., USA.

Garg, Sandhya, Ashima Goyal and Rupayan Pal (2014), “Why Tax Effort Falls Short of Capacity in Indian States: A Stochastic Frontier Approach", IGIDR Working Paper No: WP-2014032. 
Jha, Raghbendra, M. S. Mohanty, Somnath Chatterjee and Puneet Chitkara (1999), "Tax efficiency in selected Indian states", Empirical Economics, 24(4): 641-654.

Karnik, Ajit and Swati Raju (2015), "State Fiscal Capacity and Tax Effort: Evidence for Indian States", South Asian Journal of Macroeconomics and Public Finance, 4(2): 141-177.

Langford, ben and Tim Ohlenburg (2016), "Tax Revenue Potential and Effort: An Empirical Investigation", Working Paper S-43202-HGA-1, International Growth Centre.

Le, Tuan Minh, Blanca Moreno-Dodson and Nihal Bayraktar (2012), "Tax Capacity and Tax Effort: Extended Cross-Country Analysis from 1994 to 2009", Policy Research Working Paper 6252, the World Bank: Washington, D.C.

Mikesell, John (2007), "Changing State Fiscal Capacity and Tax Effort in an Era of Devolving Government, 1981-2003", Publius: The Journal of Federalism, 37(4): 532-550.

Mukherjee, S. (2020), "Plugging Loopholes in Taxation of Interstate Sales", Economic and Political Weekly, 55(19): 18-20.

Mukherjee, S. (2019), "Value Added Tax Efficiency across Indian States: Panel Stochastic Frontier Analysis", Economic and Political Weekly, 54(22):40-50, 2019.

Nerudova, D. and M. Dobranschi (2019), "Alternative method to measure the VAT gap in the EU: Stochastic tax frontier model approach", PLOS ONE, 14(1): e0211317. https://doi.org/10.1371/journal.pone.0211317.

Oommen, M. A. (1987): “Relative Tax Effort of States”, Economic and Political Weekly, 22(11): 466-470.

Purohit, M. C. (2006): "Tax Efforts and Taxable Capacity of Central and State Governments", Economic and Political Weekly, 41(8): 747-751+753-755.

Rao, H. (1993): “Taxable Capacity Tax-Efforts and Forecasts of Tax-Yield of Indian States”, ISEC. Available at http://203.200.22.249:8080/jspui/bitstream/123456789/45/1/Taxable_capacity_f or_tax_efforts_and_forecast.pdf

Sen, Tapas K. (1997), "Relative tax Effort by Indian States", Working Paper No. 5, National Institute of Public Finance and Policy (NIPFP), New Delhi.

Stotsky, J. G. and A. WoldeMariam (1997), "Tax Effort in Sub-Saharan Africa", IMF Working Paper 97/107, Washington: International Monetary Fund.

Thimmaiah, G. (1979), "Revenue Potential and Revenue Efforts of Southern States”, A study sponsored by the Planning Commission, Government of India, New Delhi.

Wang, Hung-Jen and Peter Schmidt (2002), "One-Step and Two-Step Estimation of the Effects of Exogenous Variables on Technical Efficiency Levels", Journal of Productivity Analysis, 18: 129-144. 


\section{Working Paper No. 310}

\section{Appendix}

Table A.1: Estimation of Revenue Subsumed in GST for Gujarat (INR 10 million)

\begin{tabular}{|l|c|c|c|c|c|c|}
\hline Tax Heads & $2012-13$ & $2013-14$ & $2014-15$ & $2015-16$ & $2016-17$ & $\begin{array}{c}2017-18 \text { (Upto } \\
\text { June 2017) }\end{array}$ \\
\hline $\begin{array}{l}\text { Revenue Under Protection } \\
\text { (RUP) in GST (A)\# }\end{array}$ & & & & $28,856.39$ & & \\
\hline $\begin{array}{l}\text { Sum Total of 0040, 0044* } \\
0045 \text { (B) }\end{array}$ & $39,872.90$ & $41,534.46$ & $44,629.51$ & $44,604.18$ & $46,888.63$ & $30,052.36$ \\
\hline RUP as \% of B (C) & & & & $\mathbf{6 4 . 6 9}$ & & \\
\hline Sum of 0044*(D) & 0.0001 & 0.0181 & 0.0003 & 0.0042 & 0.0112 & 0.0027 \\
\hline Sum of 0045** (E) & 188.89 & 208.42 & 191.10 & 201.51 & 226.84 & 85.50 \\
\hline Sum of (D) \& (E) (F) & 188.89 & 208.44 & 191.10 & 201.52 & 226.85 & 85.51 \\
\hline A-F (G) & & & $28,654.87$ & & $27,575.75$ \\
\hline Total of 0040***(H) & $38,566.03$ & $40,255.20$ & $43,061.27$ & $42,921.59$ & $44,709.20$ & 2 \\
\hline $\begin{array}{l}\text { G as \% of H (I) } \\
\text { 64.69\% (C of 2015-16) of } \\
\text { B (J) }\end{array}$ & $25,795.52$ & $26,870.46$ & $28,872.78$ & & $30,334.30$ & $19,442.18$ \\
\hline J - F (K) & $25,606.63$ & $26,662.02$ & $28,681.68$ & & $30,107.45$ & $19,356.68$ \\
\hline K as \% of H (L) & 66.40 & 66.23 & 66.61 & & 67.34 & 70.19 \\
\hline $\begin{array}{l}\mathbf{6 6 . 7 6} \% \text { (I of 2015-16) of } \\
\text { H (M) }\end{array}$ & $25,747.06$ & $26,874.77$ & $28,748.13$ & & $29,848.30$ & $18,409.84$ \\
\hline $\begin{array}{l}\text { Estimated Revenue from } \\
\text { Taxes Subsumed under } \\
\text { GST (N) (M+F) }\end{array}$ & $\mathbf{2 5 , 9 3 5 . 9 5}$ & $\mathbf{2 7 , 0 8 3 . 2 1}$ & $\mathbf{2 8 , 9 3 9 . 2 3}$ & $\mathbf{2 8 , 8 5 6 . 3 9}$ & $\mathbf{3 0 , 0 7 5 . 1 5}$ & $\mathbf{1 8 , 4 9 5 . 3 5}$ \\
\hline
\end{tabular}

Notes: \#-As available in the public domain.

*-Includes only 101-Tax on Telephone Billing, 102-Tax on General Insurance Premium, and 105-Courier Service under 0040-Services Tax

**-Excludes 108-Receipts under Education Cess Act, 800-Other receipts, and 901-Share of Net Proceeds assigned to States from 0045-Other Taxes and Duties on Commodities and $\underline{\text { Services }}$

***-Excludes 103-Tax on sale of motor spirit and lubricants, 105-Tax on Sale of Crude oil, 800-Other receipts from 0040-Taxes on Sales, Trade, etc.

Source: Estimated from State Finance Account Data (various years) 
Table A.2: Estimation of Revenue Subsumed in GST for Haryana (INR 10 million)

\begin{tabular}{|l|r|r|r|r|r|r|}
\hline Tax Heads & $\mathbf{2 0 1 2 - 1 3}$ & $\mathbf{2 0 1 3 - 1 4}$ & $\mathbf{2 0 1 4 - 1 5}$ & $\mathbf{2 0 1 5 - 1 6}$ & $\mathbf{2 0 1 6 - 1 7}$ & $\mathbf{2 0 1 7 - 1 8}$ \\
\hline $\begin{array}{l}\text { Revenue Under Protection } \\
\text { (RUP) in GST (A)\# }\end{array}$ & & & & $15,230.59$ & & \\
\hline $\begin{array}{l}\text { Sum Total of 0040, 0042* } \\
\text { 0045 (B) }\end{array}$ & $15,464.74$ & $16,859.08$ & $19,118.65$ & $21,169.01$ & $23,682.54$ & $17,973.01$ \\
\hline RUP as \% of B (C) & & & & 71.95 & & \\
\hline Sum of 0042* \& 0045**(D) & 81.32 & 78.13 & 115.64 & 100.94 & 190.89 & $2,359.88$ \\
\hline A-D (E) & & & & $15,129.65$ & & \\
\hline Total of 0040***(F) & $15,376.57$ & $16,549.64$ & $18,969.84$ & $21,045.69$ & $23,481.04$ & $15,605.17$ \\
\hline E as \% of F (G) & & & 71.89 & & \\
\hline $\begin{array}{l}\mathbf{7 1 . 8 9 \%}(G \text { of 2015-16) of B } \\
\text { (H) }\end{array}$ & $11,117.53$ & $12,119.91$ & $13,744.31$ & & $17,025.26$ & $12,920.71$ \\
\hline H - D (I) & $11,036.21$ & $12,041.78$ & $13,628.67$ & & $16,834.37$ & $10,560.83$ \\
\hline I as \% of F (J) & 71.77 & 72.76 & 71.84 & & 71.69 & 67.68 \\
\hline $\begin{array}{l}\mathbf{7 1 . 8 9} \% \text { (G of 2015-16) of F } \\
\text { (K) }\end{array}$ & $11,054.14$ & $11,897.46$ & $13,637.33$ & & $16,880.41$ & $11,218.48$ \\
\hline $\begin{array}{l}\text { Estimated Revenue from } \\
\text { Taxes Subsumed under GST } \\
\text { (L) (K+D) }\end{array}$ & $\mathbf{1 1 , 1 3 5 . 4 6}$ & $\mathbf{1 1 , 9 7 5 . 5 8}$ & $\mathbf{1 3 , 7 5 2 . 9 7}$ & $\mathbf{1 5 , 2 3 0 . 5 9}$ & $\mathbf{1 7 , 0 7 1 . 3 0}$ & $\mathbf{1 3 , 5 7 8 . 3 6}$ \\
\hline
\end{tabular}

Notes: \#-As available in the public domain.

*-Includes only 106-Tax on entry of goods into Local areas under 0042 Taxes on Goods and Passengers

**-Excludes 114-Receipts under Sugarcane (Regulation, Supply and Purchase Control) Act, 800-Other Receipts, and 901-Share of net proceeds assigned to States from 0045-Other taxes and Duties on Commodities and Services

***-Excludes 103-Tax on Sale of Motor Spirits \& Lubricants and 800-Other Receipts from 0040-Taxes on Sales, Trade etc.

Source: Estimated from State Finance Account Data (various years) 
Table A.2: Estimation of Revenue Subsumed in GST for Arunachal Pradesh (INR 10 million)

\begin{tabular}{|l|c|c|c|c|c|c|}
\hline \multicolumn{1}{|c|}{ Tax Heads } & $2012-13$ & $2013-14$ & $2014-15$ & $2015-16$ & $2016-17$ & $2017-18$ \\
\hline $\begin{array}{l}\text { Revenue Under Protection (RUP) } \\
\text { in GST (A)\# }\end{array}$ & 161.62 & 223.60 & 195.24 & 308.31 & 563.71 & 414.09 \\
\hline $\begin{array}{l}\text { Sum Total of 0040, 0042* } \\
0045^{* *} \text { (B) }\end{array}$ & & & & 83.04 & & \\
\hline RUP as \% of B (C) & 134.22 & 185.68 & 162.13 & 256.03 & 468.12 & 343.87 \\
\hline $\begin{array}{l}\text { Estimated Revenue from Taxes } \\
\text { Subsumed under GST (D) } \\
{[83.04 \% \text { (C of 2015-16) of B] }}\end{array}$ & & & & & \\
\hline
\end{tabular}

Notes: \#-As available in the public domain.

*-Includes only 106-Tax on entry of goods into Local areas under 0042 Taxes on Goods and Passengers

** - Excludes 901-Share of net proceeds assigned to States from 0045-0ther taxes and Duties on Commodities and Services

Source: Estimated from State Finance Account Data (various years) 
- Shah, A., (2020). Responding to the new coronavirus: An Indian policy perspective (Submitted on March II, 2020), W.P. No. 309 (July).

- $\quad$ Pandey, R., Kedia, S., and Malhotra, A., (2020).

Addressing Air Quality Spurts due to Crop Stubble Burning during COVID-I9 Pandemic: A case of Punjab, WP No. 308 (June).

- Anand, A., and Chakraborty, L., (2020). Impact of Negative Interest Rate Policy on Emerging Asian markets: An Empirical Investigation, WP No. 307 (June).
Sacchidananda Mukherjee, is Associate Professor, NIPFP

Email: sacchidananda.mukherjee@nipfp.org.in

\section{NP辰}

National Institute of Public Finance and Policy, 18/2, Satsang Vihar Marg,

Special Institutional Area (Near JNU),

New Delhi 110067

Tel. No. 26569303, 26569780, 26569784

Fax: 91-11-26852548

www.nipfp.org.in 